\title{
Kajian Molekuler Layu Buah Muda Kakao (Theobroma cacao L.): Ekspresi TcPIN1 Like Gene
}

\section{Molecular Study of Cherelle Wilt in Cocoa (Theobroma cacao L.): Expression of TcPIN1 Like Gene}

\author{
Yohana Theresia Maria Astuti ${ }^{1 *}$, Kumala Dewi ${ }^{2}$, Santosa $^{2}$ dan A. Adi Prawoto ${ }^{3}$ \\ ${ }^{I}$ Fakultas Pertanian, Institut Pertanian Stiper, Jl. Petung no 2, Papringan, Yogyakarta \\ ${ }^{2}$ Fakultas Biologi, Universitas Gadjah Mada, Yogyakarta \\ ${ }^{3}$ Puslit Kopi dan Kakao Indonesia, Jember \\ E-mail: astuti_maria2000@yahoo.com*Penulis untuk korespondensi
}

\begin{abstract}
This experiment was carried out to evaluate the expression of TcPIN1 like gene in cocoa (Theobroma cacao L.). DNA and RNA were extracted from 7 weeks old of both healthy and cherelle wilt cocoa pods. PCR was done with two primer set based on PIN1 sequenced of Arabidopsis. Primer PIN1-1: Forward: taaggtgatgccaccaacaa; Reverse: gccatgaacaacccaagact. Primer PIN!-2: Forward: tttgtgtggagctcaagtgc; Reverse: ctgcgtcgttttgttgctta. RT-PCR was done with primer PIN1-2. The results showed that TcPIN1-2 like gene was found in healthy young pods, but not availabe in cherelle wilt pods of cocoa.
\end{abstract}

Key words: Theobroma cacao L., Cherelle wilt, DNA, RNA, TcPIN1

\begin{abstract}
Abstrak
Penelitian ini bertujuan untuk mengevaluasi ekspresi TcPIN1 like gene pada buah kakao (Theobroma cacao L.). DNA dan RNA diekstrak dari buah kakao yang sehat dan layu yang berumur 7 minggu. PCR dilakukan dengan dua set primer dari sekuens PIN1 Arabidopsis. Primer PIN1-1: Forward: taaggtgatgccaccaacaa; Reverse: gccatgaacaaccaagact. Primer PIN!-2: Forward: tttgtgtggagctcaagtgc; Reverse: ctgcgtcgttttgttgctta. RT-PCR dilakukan dengan primer PIN1-2. Hasil penelitian menunjukkan bahwa pada buah muda yang sehat dapat ditemukan ekspresi TcPIN1-2 like gene, tetapi tidak ditemukan pada cherelle wilt kakao.
\end{abstract}

Kata kunci: Theobroma cacao L., Cherelle wilt, DNA, RNA, TcPIN1

Diterima: 03 Maret 2010, disetujui: 01 September 2010

\section{Pendahuluan}

Kakao (Theobroma cacao L) merupakan salah satu tanaman perkebunan yang penting dan merupakan komoditas unggulan di beberapa negara penghasil kakao, termasuk Indonesia. Dari sejumlah besar buah kakao yang terbentuk, tidak semua buah muda dapat tumbuh dan berkembang sampai masak. Pada umumnya, sebagian buah muda akan layu dan mati (Tjasadihardja, 1981; Aneja, 1999). Peristiwa ini disebut cherelle wilt atau layu buah muda kakao/ layu pentil kakao. Cherelle wilt ditandai dengan perubahan warna pada kulit buah yang semula berwarna merah atau hijau (tergantung klon kakao tersebut) menjadi kekuningan yang kemudian akan semakin berwarna coklat dan akhirnya layu (Prawoto, 2000). Pada umumnya cherelle wilt terjadi pada buah muda yang berukuran kurang dari $10 \mathrm{~cm}$ atau berumur kurang dari 10 minggu (Prawoto, 2000). Tingkat layu buah muda pada kakao dapat mencapai 40-70\% (Prawoto, 2000).

Baik faktor internal maupun eksternal dapat menyebabkan cherelle wilt. Salah satu faktor internal yang diperkirakan mengontrol cherelle wilt adalah hormon, karena kandungan hormon juga menentukan perkembangan biji (Bewley dan Black, 1994). Pada buah muda yang mengalami cherelle wilt sering tidak ditemukan auksin atau ditemukan dengan kadar yang rendah. Terlalu rendahnya kadar auksin 
diduga menyebabkan hambatan perkembangan embrio sehingga sink strength terhadap fotosintat menjadi lemah (Prawoto, 2000).

Hasenstein dan Zavada (2001) melaporkan aplikasi napthalene acetic acid (NAA) pada konsentrasi $5,10^{-5} \mathrm{M}$ dapat menginduksi tahap awal perkembangan buah sehingga meningkatkan keberhasilan pembentukan buah kakao. Kekurangan auksin endogen kemungkinan menyebabkan sink strength buah menurun sehingga buah tidak mampu mengatasi kompetisi fotosintat dengan buah lainnya dan tunas di dekatnya. Hal ini menunjukkan bahwa keterbatasan kandungan auksin dalam buah dapat menjadi penyebab layu buah muda kakao.

Auksin dikenal mempunyai banyak peran dalam pertumbuhan tanaman diantaranya pada saat perkembangan biji. Pada saat biji berkembang, auksin berperan pada pembentukan meristem apikal calon batang dan akar. Auksin ditranspor dari sel ke sel dengan bantuan auxin influx carrier yang dikode oleh gen AUX1 dan auxin efflux carrier yang dikode oleh beberapa gen PIN (Jenik dan Barton, 2005).

Empat anggota gen auxin efflux carrier PIN yang diekspresi di dalam embrio Arabidopsis adalah AtPIN1, AtPIN3, AtPIN4 dan AtPIN7. Ekspresi protein PIN berpengaruh pada pola akumulasi auksin di dalam embrio. Hal ini berkaitan dengan perkembangan aksis apikal dan basal embrio (Friml et al., 2003 dalam Jenik dan Barton, 2005). Mekanisme cherelle wilt dari sudut hormonal diharapkan dapat dilacak melalui analisis molekuler, salah satunya terhadap gen yang homolog dengan AtPIN1 pada buah kakao sehat dan layu. Tujuan penelitian ini adalah memperoleh gambaran ekspresi TcPIN1 like gene pada buah kakao sehat dan buah yang layu.

\section{Metode Penelitian}

\section{Bahan Buah Kakao}

Penelitian dilakukan pada bulan Maret sampai Oktober 2009. Sampel buah kakao diperoleh dari Kebun Percobaan Kaliwining, Pusat Penelitian Kopi dan Kakao Indonesia di Jember, sedangkan ekstraksi PIN1 like gene dilakukan di Laboratorium Bioteknologi, Pusat
Antar Universitas Universitas Gadjah Mada, Yogyakarta.

Buah muda kakao yang digunakan dalam penelitian ini berasal dari pohon kakao klon $\mathrm{KW}$ 163 (self compatible) dan kakao klon KW 165 (self incompatible). Buah muda diperoleh melalui hand pollination.

\section{Penyerbukan dan Pemeliharaan Buah}

Penyerbukan dilakukan secara buatan dengan tahapan berikut: kuntum bunga yang hampir mekar dikerodong menggunakan botol plastik kecil. Pada hari berikutnya saat bunga tersebut mekar, tutup dibuka dan penyerbukan dilakukan. Polen diambil menggunakan pinset kemudian dioleskan pada kepala putik kemudian bunga ditutup kembali. Setelah satu minggu, penyerbukan yang berhasil akan ditandai dengan mulai terbentuknya buah, maka kerodong dibuka. Untuk menghindari serangan hama Helopeltis dan PBK (Penggerek Buah Kakao), pentil buah kakao tersebut dikerodong menggunakan kantong plastik. Buah dipelihara sampai berumur tujuh minggu. Dalam rentang waktu tersebut umumnya akan banyak buah yang layu. Tujuh minggu setelah polinasi buatan, diambil sampel buah sehat dan layu (Cherelle wilt).

\section{Ekstraksi dan Amplifikasi Genomic DNA Buah Kakao}

Isolasi DNA dilakukan berdasarkan metode ekstraksi DNA oleh Haymes et al., (2004). Sebanyak $50 \mathrm{mg}$ buah kakao digerus di dalam mortar sampai halus dan ditambah dengan $1 \mathrm{~mL}$ buffer ekstraksi DNA (100 mM Tris $\mathrm{HCl}$, pH 8,0, 1,4 M NaCl, 20 mM EDTA, 2\% CTAB, $0,4 \% \quad \beta$-mercaptoethanol), kemudian digojok dengan vortex. Sampel diinkubasi dalam water bath pada suhu $60^{\circ} \mathrm{C}$ selama 1 jam, setiap 15 menit divortex. Setelah itu ditambahkan $0,5 \mathrm{~mL}$ $\mathrm{CHCl}_{3}$ / isoamylalcohol (24:1), divortex, kemudian dipusingkan (centrifuge) pada kecepatan $12.000 \mathrm{~g}$ selama 5 menit. Fase atas dipindahkan ke tabung bersih 1,5 mL, kemudian diekstraksi lagi menggunakan $\mathrm{CHCl}_{3}$ / isoamylalcohol berulang-ulang sampai jernih. Setelah jernih, DNA dilarutkan ke dalam 1,0 mL 95\% ethanol dingin, disimpan di dalam freezer semalam. Sampel selanjutnya dipusingkan pada kecepatan $12.000 \mathrm{~g}$ selama 5 menit. Pellet dicuci 
menggunakan etanol 70\%, kemudian etanol diuapkan sampai habis. Sampel dilarutkan ke dalam buffer TE (10 mM Tris $\mathrm{HCl}, \mathrm{pH} 8,0$ dan 1 mM EDTA,pH 8,0).

"Polymerase Chain Reaction" (PCR) dilakukan menggunakan "Ready PCR MegaMix Blue" (MMB) dari Microzone Ltd. Dua (2) set primer yang digunakan dalam PCR. ditentukan berdasarkan sekuens gen PIN1 pada Arabidopsis (GenBank accession number AF 089084):

Primer 1 (PIN1-1): Forward: taaggtgatgccaccaa caa dan Reverse: gccatgaacaacccaagact

Primer 2 (PIN1-2): Forward: tttgtgtggagctcaa gtgc dan Reverse: ctgcgtcgttttgttgctta

Program PCR terdiri dari predenaturasi pada suhu $94^{\circ} \mathrm{C}$ selama 5 menit, dilanjutkan dengan 30 siklus yang terdiri dari denaturasi pada suhu $94^{\circ} \mathrm{C}$ selama 30 detik, annealing pada suhu $53^{\circ} \mathrm{C}$ selama 1 menit dan extension $72^{\circ} \mathrm{C}$ selama 1 menit. Pada tahap terakhir proses PCR dilakukan final extension pada suhu $72^{\circ} \mathrm{C}$ selama 10 menit. Hasil PCR disimpan pada suhu $-20^{\circ} \mathrm{C}$. Sebanyak $5 \mu \mathrm{L}$ produk PCR hasil amplifikasi dianalisis menggunakan elektroforesis pada gel agarosa $1,2 \%$ dengan standar DNA ladder sebanyak $10 \mu \mathrm{L}$.

\section{Ekstraksi RNA dan RT-PCR dari Buah Kakao}

Ekstraksi RNA dilakukan dengan Qiagen RNeasy Plant Mini Kit (20) cat no. 74903 (Kit berisi antara lain: Rneasy Mini Spin Column, buffer RLC, buffer RW1 dan buffer RPE). Sebanyak $100 \mathrm{mg}$ buah kakao yang telah digerus diletakkan pada $2 \mathrm{~mL}$ tabung bebas RNAse, ditambahkan $450 \mu \mathrm{L}$ buffer RLC, dipindahkan dalam "spin column" dalam tabung $2 \mathrm{~mL}$, kemudian dipusingkan selama 2 menit pada kecepatan 12.000 g. Supernatan dipindahkan ke tabung baru, ditambahkan 0.5 volume ethanol 96\%. Larutan dipindahkan ke dalam "spin column" dalam tabung $2 \mathrm{~mL}$, dipusingkan selama 15 detik. Supernatan dipindahkan ke dalam tabung baru, selanjutnya ditambahkan 700 $\mu \mathrm{L}$ buffer RW1 dan dipusingkan lagi selama 15 detik. Ditambahkan kembali $500 \mu \mathrm{L}$ buffer RPE, dan dipusingkan selama 2 menit. "Spin column" diletakkan pada tabung yang baru, ditambahkan $30 \mu \mathrm{L}$ aquades bebas RNAse, dipusingkan selama 1 menit. RNA diperoleh di dalam tabung koleksi.
RT-PCR (Reverse Transcriptase PCR) dilakukan dengan reagen Qiagen LongRange 2Step RT-PCR. Master mix RT-PCR untuk langkah I dicampur homogen dengan $4 \mu \mathrm{L}$ RNA, digojog menggunakan vortex dan dipusingkan sebentar untuk mengumpulkan larutan dalam tabung. Sampel diinkubasi pada suhu $42^{\circ} \mathrm{C}$ selama 90 menit, selanjutnya inaktivasi enzim dilakukan pada suhu $85^{\circ} \mathrm{C}$ selama 5 menit. Dilanjutkan dengan langkah II yang merupakan amplifikasi cDNA dengan primer PIN1-2 (Forward: tttgtgtggagctcaagtgc dan Reverse: ctgcgtcgtttt gttgctta) dengan program PCR yang terdiri dari initial aktivasi pada suhu $93^{\circ} \mathrm{C}$ selama 3 menit, dilanjutkan dengan 35 siklus yang terdiri dari denaturasi pada suhu $93^{\circ} \mathrm{C}$ selama 15 detik, annealing pada suhu $50^{\circ} \mathrm{C}$ selama 30 detik dan extension $68^{\circ} \mathrm{C}$ selama 1 menit. Pada tahap terakhir proses PCR dilakukan final extension pada suhu $68^{\circ} \mathrm{C}$ selama 8 menit. Hasil PCR disimpan pada suhu $-20^{\circ} \mathrm{C}$. Sebanyak $5 \mu \mathrm{L}$ produk PCR dianalisis dengan elektroforesis pada gel agarosa 1,2\% dengan standar DNA ladder sebanyak $10 \mu \mathrm{L}$.

\section{Hasil dan Pembahasan}

\section{Buah Kakao}

Gambar 1a dan 1b memperlihatkan buah kakao umur 7 minggu yang sehat dan yang mengalami cherelle wilt. Buah yang sehat memiliki biji warna putih dan kelihatan padat, sedangkan buah yang layu memiliki biji mengecil dengan warna lebih gelap. Penentuan pengambilan sampel buah yang berumur 7 minggu berdasarkan hasil dari beberapa penelitian yang menunjukkan bahwa buah layu umumnya terjadi sebelum berumur 10 minggu dan persentase layu terbanyak pada umur 7-8 minggu (Prawoto, 2000; Thorold, 1975).

\section{Ekstraksi dan Amplifikasi Genomic DNA Buah Kakao}

Gambar 2 memperlihatkan hasil ekstraksi DNA dengan metode CTAB (hexadecyltrimethylammonium bromide) dari Haymes et al., (2004). Buah kakao banyak mengandung polifenol dan polisakarida. Pemisahan senyawa polifenol tersebut dari asam nukleat merupakan kesulitan utama pada proses isolasi DNA 
(Chaidamsari, 2006; Gesteira et al., 2003; Haymes et al., 2004). Pada penelitian ini, polifenol dihilangkan melalui banyak tahap pencucian dengan CIAA (chloroformisoamylalcohol) sehingga diperoleh gambaran DNA genom dari buah kakao sehat klon KW 163 dan KW 165.

Gambar 3 adalah hasil PCR TcPIN1-1 dan TcPIN1-2 dari DNA genom buah muda kakao. Gambar 3a adalah hasil amplifikasi DNA genom buah kakao sehat klon KW 165 dengan primer PIN1-1 dan primer PIN1-2. Primer PIN1-1 tidak memberikan hasil, sedangkan primer PIN1-2 memberikan hasil amplifikasi dengan band sekitar 300bp. Gambar 3b memperlihatkan hasil amplifikasi TcPIN1-2 dari DNA genom buah kakao sehat klon KW 163 dan KW 165. Hal ini menunjukkan bahwa di dalam buah kakao sehat terekspresi TcPIN1-2.

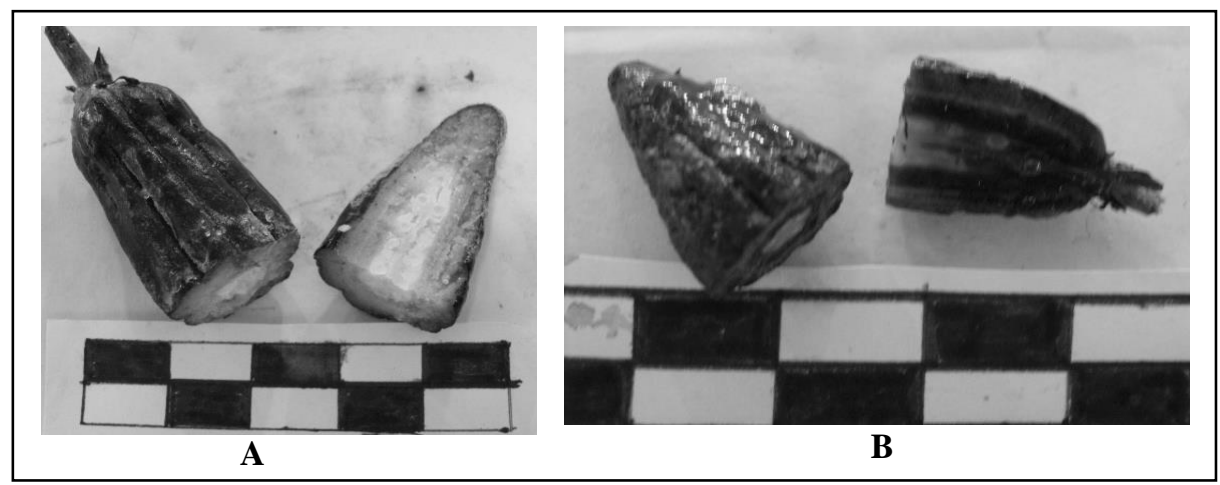

Gambar 1. Buah Kakao sehat (a) dan layu (b) umur 7 minggu.

Keterangan: $\square=1 \mathrm{~cm}$

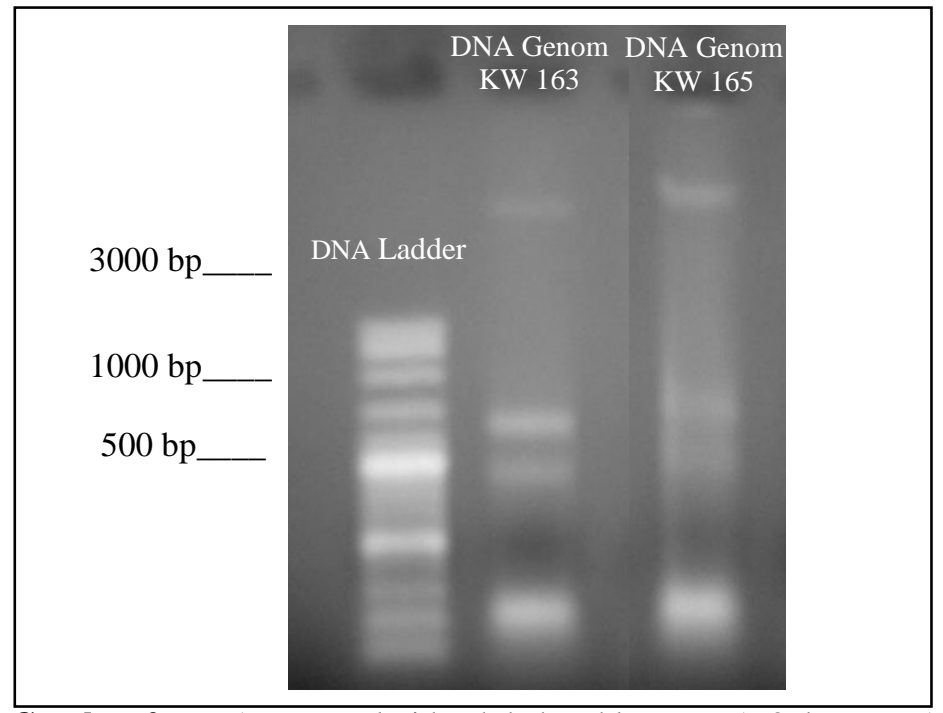

Gambar 2. DNA genom dari buah kakao klon KW 163 dan KW 165.

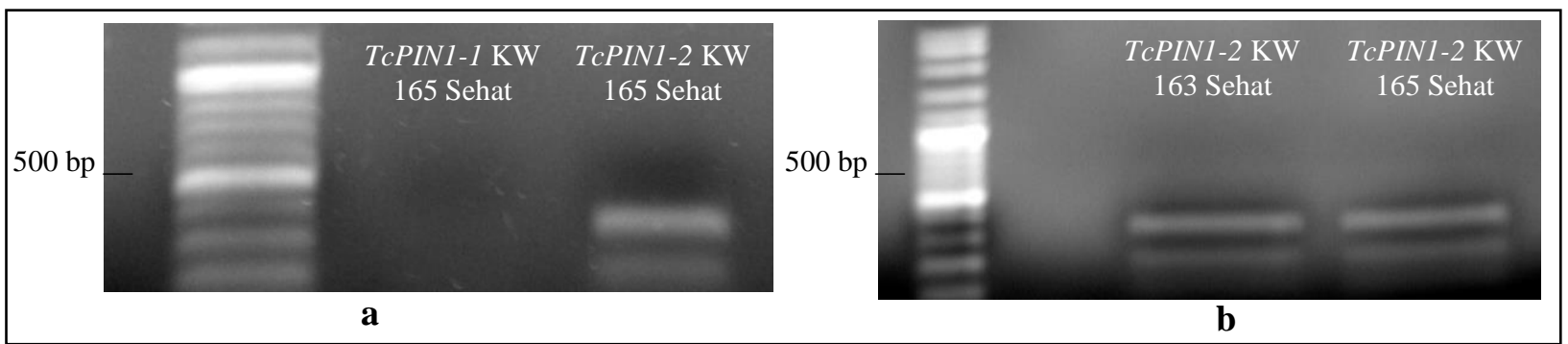

Gambar 3. Amplifikasi TcPIN1-1 dan TcPIN1-2 dari buah kakao sehat klon KW 165 (a) dan Amplifikasi TcPIN1-2 dari buah kakao sehat klon KW 163 dan KW 165 (b). 


\section{Ekstraksi RNA dan Ekspresi TcPIN1 like gene Buah Kakao}

Gambar 4 menunjukkan hasil ekstraksi RNA dari buah kakao sehat dan layu dari klon KW 163 dan KW 165. Terlihat pada gambar 4 tersebut, RNA dapat diekstraksi dari buah kakao yang sehat, sedangkan dari buah umur 7 minggu yang layu (cherelle wilt) tampak sudah terjadi degradasi.

Gambar 5 menunjukkan hasil amplifikasi TcPIN1 like gene dari cDNA buah kakao sehat dengan primer PIN1-2. Hasil ekstraksi RNA dari buah layu yang dilanjutkan dengan sintesis cDNA dan PCR, tidak diperoleh amplifikasi ekspresi TcPIN1 like gene. PIN1 adalah gen yang mengkode transpor auksin antar sel. Gen tersebut, meskipun bisa ditemukan di dalam biji, konsentrasinya amat rendah serta tidak stabil. Gen tersebut terekspresi hanya apabila ada aktivitas transport auksin dari sel ke sel. Hal ini sesuai dengan pernyataan Jenik \& Barton (2005) serta Paponov et al., (2005) bahwa PIN1 adalah salah satu dari empat anggota gen fasilitator auxin efflux carrier PIN yang diekspresi di dalam embrio Arabidopsis yang sedang berkembang disamping PIN3, PIN4 dan PIN7. Oleh karena perannya, maka ekspresi PIN berpengaruh pada pola akumulasi auksin di dalam embrio. Di samping itu, Jones et al., (2005) menyatakan bahwa selain berperan dalam transport auksin, kemungkinan PIN1 juga berperan dalam biosintesis auksin.

Hasil penelitian ini menunjukkan bahwa di dalam buah kakao sehat, terdapat transpor auksin yang dibutuhkan untuk perkembangan embrio serta buah. Pada buah layu, tidak ditemukan ekspresi gen yang berperan dalam transpor auksin. Dengan demikian diketahui bahwa pada buah sehat, auksin mempunyai peran penting dalam pertumbuhan dan perkembangan embrio. Pada buah layu, tidak terjadi transport auksin yang memberikan indikasi tidak ada lagi perkembangan embrio di dalamnya. Meskipun demikian, hasil penelitian ini masih belum bisa menggambarkan mekanisme cherelle wilt. Ekspresi TcPIN1 like gene masih perlu dievaluasi pada buah kakao dengan berbagai variasi umur sehingga diketahui awal terjadinya hambatan dalam transport auksin.

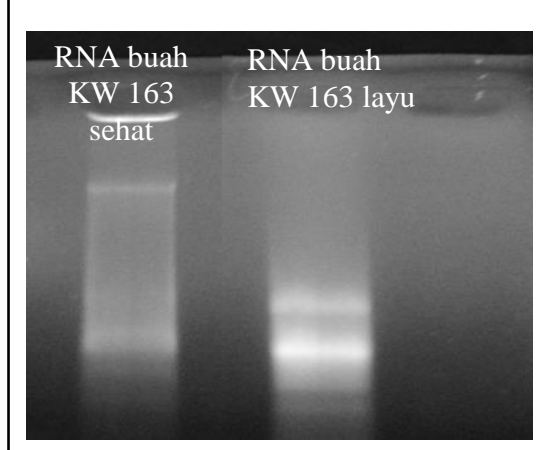

(a)

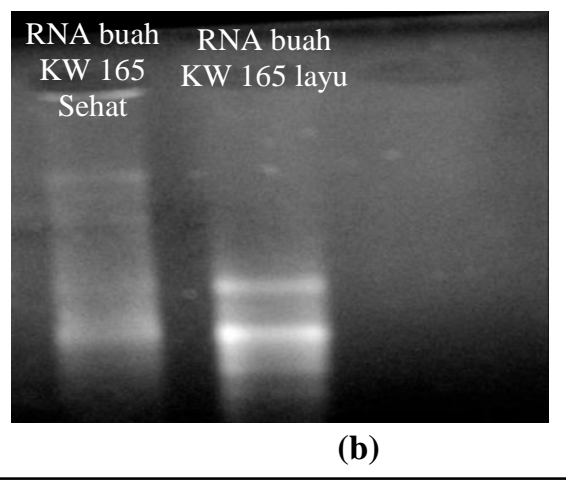

(b)

Gambar 4. RNA dari buah kakao KW 163 (a) dan KW 165 (b).

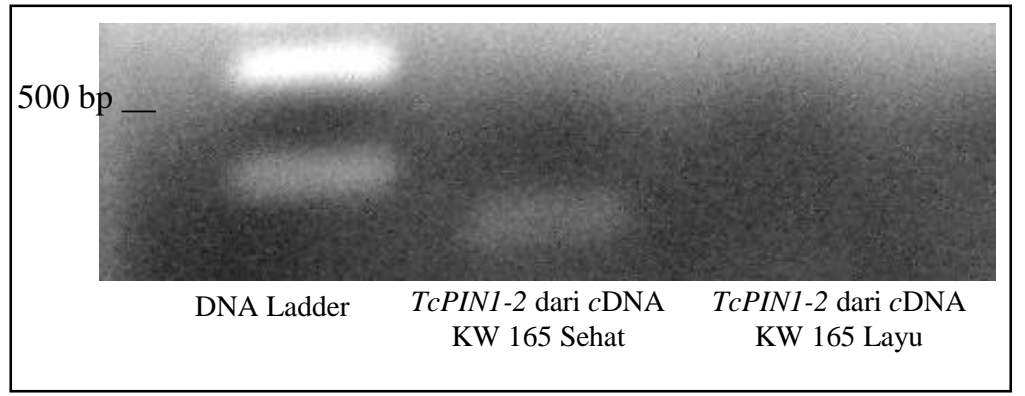

Gambar 5. TcPIN1 like gene dari cDNA. 


\section{Simpulan dan Saran}

\section{Simpulan}

Simpulan dari hasil penelitian ini adalah TcPIN1 like gene terekspresi pada buah sehat, sebaliknya pada buah layu, tidak ditemukan ekspresi TcPIN1 like gene. Perubahan ekspresi TcPIN1 like pada buah kakao dengan berbagai variasi umur belum dapat memberikan gambaran mekanisme terjadinya cherelle wilt.

\section{Saran}

Mengacu pada hasil penelitian, saran untuk dilakukan penelitian lebih lanjut mengenai studi ekspresi TcPIN1 like gene dalam berbagai umur perkembangan buah kakao.

\section{Ucapan Terima Kasih}

Terima kasih diucapkan kepada Dr. Endang Semiarti dalam memperoleh primer PIN1 dan kepada Sdri Arsiyah yang membantu dalam pekerjaan di laboratorium Bioteknologi Universitas Gadjah Mada Yogyakarta.

\section{Daftar Pustaka}

Aneja, M., Gianfagna, T. dan Ng, E. 1999. The Role of Abscisic Acid and Ethylene in The Abscission and Senescence of Cocoa Flower. Plant Growth Regulation, 27: 149-155.

Bewley, J.D. dan Black, M. 1983. Physiology and Biochemistry of Seeds. Springer-Verlag Berlin. Heidelberg. New York.

Chaidamsari, T., Samanhudi, Sugiarti, H., Santoso, D., Angenent, G. dan de Maagd, R.A. 2006. Isolation and Characterization of AGAMOUS Homologue from Cocoa. Plant Science, 170: 968-975.

Gesteira, A.S., Micheli, F., Ferreira, C.F. dan Cascardo, J.C.M. 2003. Isolation and Purification of Functional Total RNA from Different Organs of Cacao Tree During its Interaction with The Pathogen Crinipellis perniciosa. BioTechniques, 35: 494-500.
Ditjen Perkebunan. 2007. Statistik Perkebunan 2006-2008. Kakao. Direktorat Jenderal Perkebunan, Departemen Pertanian. Jakarta.

Hasenstein, K.H. dan Zavada, M.S. 2001. Auxin Modification of The Incompatibility Response in Theobroma cacao. Physiologia Plantarum, 112: 113-118.

Haymes, K.M., Ibrahim, I.A., Mischke, S., Scott, D.L. dan Saunders, J.A. 2004. Rapid Isolation of DNA from Chocolate and Date Palm Tree Crops. $J$. Agric. Food Chem., 52: 5456-5462.

Jenik, P.D. dan Barton, M.K. 2005. Surge and Destroy: The Role of Auxin in Plant Embryogenesis. Development, 132: 3577-3585.

Jones, S.E., DeMeo, J.S., Davies, N.W., Noonan, S.E. dan Ross, J.J. 2005. Stems of the Arabidopsis PIN 1-1 Mutant are not Deficient in Free Indole-3acetic Acid. Planta, 222: 530-534.

Komisi Kakao Indonesia. 2006. Direktori dan Revitalisasi Agribisnis Kakao Indonesia. Departemen Pertanian. Jakarta.

Morris, D.A. 1996. Hormonal Regulation of Source - Sink Relationships: An Overview of Potential Control Mechanisms. In: Zamski, E. and Schaffer, A.A. (Eds.). Photoassimilate Distribution in Plant and Crops: Source-Sink Relationships. Marcel Dekker. New York.

Paponov, I.A., Teale, W.D., Trebar, M., Blilou, I. dan Palme, K. 2005. The PIN Auxin Efflux Facilitators: Evolutionary and Functional Perspectives. Trends in Plant Science, 10 (4): 170-176.

Prawoto, A.A. 2000. Kajian Morfologis, Anatomis dan Biokhemis Layu Pentil Kakao Serta Perkembangan Upaya Pengendaliannya. Pelita Perkebunan, 16 (1): 11-29.

Tjasadihardja, A. 1987. Hubungan antara Pertumbuhan Pucuk, Perkembangan Buah serta Tingkat Kandungan Asam Indol Asetat di Dalam Biji dan Layu Pentil Kakao (Theobroma cacao L.). Desertasi. Fakultas Pasca Sarjana IPB. Bogor. 